Охорона рослинного свіму

\title{
Contribution to the study of habitat diversity in Western Stara Planina Mountain (Bulgaria)
}

\author{
ALEXANDER TASHEV \\ ANTONINA VITKOVA \\ VESKA RUSSAKOVA
}

ТАшев О., ВІтКОВА А., РуССАКОВА В., 2010: Результати вивчення різноманіття біотопів на заході гірського масиву Стара Планіна (Болгарія). Чорноморськ. бот. ж., Т. 6, № 1: 104-114.

У зв'язку з формуванням Болгарської частини Європейської екомережі NATURA 200011 типів біотопів Європейського значення були визначені на заході гірського масиву Стара Планіна (північніша частина Знепольської та західна частина Софіївської областей). Два біотопи (6240 - Суб-панонські степи та 40А0 Субконтинентальні припанонські чагарники) є приорітетними згідно 3 директивою 92/43/ЕЕС. Найбільш звичайно зустрічаються біотопи - 6510 (низинні сінокосні луки), наступні 6240 (Субпанонські степи) та 6210 (напівнатуральні сухі степи та чагарникові фації на вапняковій субстанції). Інші типи біотопів - 6520, 62А0 та 6410 були визначені 2-3 рази, а 6440, 6230 та 6110, 8210 були виявлені в одиничних формаціях. Вивчені біотопи є відомими для Болгарії, але їх точна локалізація на заході Старої Планіни наводиться вперше.

Ключові слова: місиезростання, гірський массив Стара Планіна (Захід), Болгарія

Tashev A., Vitkova A., Russakova V. 2010: Contribution to the study of habitat diversity in Western Stara Planina Mountain (Bulgaria). Chornomors'k. bot. z., Vol. 6, № 1: 104-114.

In connection with the creation of the Bulgarian part of the European ecological network NATURA 2000 eleven types of habitats of European significance have been determined in the Stara Planina Mt. (Western), the northernmost part of Znepole region and the westernmost part of Sofia region. Two habitats (6240 - Sub-pannonic steppe grasslands and 40A0 - Sub-continental peri-pannonic scrub) are of a priority according to the Directive 92/43/EEC. The habitats most commonly met are - 6510 (Lowland hay meadows), followed by 6240 (Sub-pannonic steppe grasslands) and 6210 (Semi-natural dry grasslands and scrubland facies on calcareous substrates). The rest of the habitat types $6520,62 \mathrm{~A} 0$ and 6410 have been ascertained twice or thrice and 6440, 6230 and 6110, 8210 were found as single formations. The habitats studied are known for Bulgaria, but their precise localities in the Western Stara Planina are reported for the first time.

Key words: habitats, Stara Planina Mountain (Western), Bulgaria

ТАшеВ А., ВИтКОВА А., РуССАКОВА В. 2010: Результаты изучения разнообразия биотопов на западе горного масива Стара Планина (Болгария). Черноморск. бот. ж., Т. 6, № 1: 104-114.

В связи с формированием Болгарской части Европейской экологической сети NATURA 200011 типов биотопов Европейского значения были определены на западе горного массива Стара Планина (северная часть Знепольскої и западная часть Софиевской областей). Два биотопа (6240 - Субпанонские степи и 40А0 Субконтинентальные припанонские кустарники) являются приоритетными согласно с директивой 92/43/ЕЕС. Наиболее обычно встречаются биотопы - 6510 (Низинные

(C) A. Tashev, A. Vitkova, V. Russakova

Чорноморськ. бот. ж., Т. 6, № 1: 104-114. 
сенокосные луга), а также 6240 (Субпанонские степи) и 6210 (полуестественные сухие степи и кустарниковые фации на известковой субстанции). Другие типы биотопов - 6520, 62А0 и 6410 были определены 2-3 раза, а 6440, 6230 иа 6110,8210 были виявлены в единичных формациях. Изученные биотопы являются известными для Болгарии, но их точная локализация на западе Старой Планины приводится впервые.

Ключевые слова: местообитание, горный массив Стара Планина (Западная), Болгария

In the last few years, investigations regarding the conservation of the natural habitats are of priority, which create possibilities for preservation of plant and animal species and cenoces. Special attention is paid to the priority types of habitats that are elements of the European Network of territories with special protection - NATURA 2000, adopted by the European Union in 1992 and developed afterwards. The applications to this document point out all nature habitats of social interest, as well as list of plant and animal species, which conservation requires declaration of special protected territories. In 2002 Bulgaria adopted special Act on Biodiversity, which was changed and supplemented in 2005. With respect to the application of this document regular investigations were carried out on the types of habitats in the country. A part of them is presented here below.

The studied territory includes hygrophyte, mesophyte and xerotermic habitats. Almost everywhere the soil-forming rocks on the southern slopes of Stara Planina Mt.(Western) are Jurassic and Cretacean limestones and marls. Limestone terrains consisting of marl cover the hills near towns Dragoman and Slivnitza. The limestone rocks, occurring on the surface in many places, cause a definite influence on the characteristics of habitats, the composition and structure of the plant coverage. The soils on the southern slopes predominating in the region are often stony, shallow and rather dry during the vegetation period. The plant communities are dominated by thermophyllous and xerophyte elements and many of them strongly depend on the limestone. Except these habitats, along the river valleys of Nishava, Iskar and its tributaries - Gabrovnitza, Kriva Reka in some plain or slightly inclined terrains the ecological conditions are hygrophyte (quite rarely) or mesophyte. This is a prerequisite for development of meadow vegetation and such habitats supplement the whole mosaic of the region of study. There is only one sector along the river valley of Nishava, where it engraves into the limestone rocks and was formed canyon.

The development of calciphyte vegetation on the limestone slopes of the mountain and the adjacent hills influences the floristic composition. This is true also for the adjacent plain territories, where some calciphyte species rare for the country and the region of western Bulgaria occur, as well as species of steppe character.

Up to date, no complete investigation on the habitat variability in the Stara Planina Mt. (Western), northernmost parts of Znepole region and westernmost parts of Sofia floristic region exists. The vegetation was investigated only in separate parts and regions. VELCHEV [1962] carried out a geo-botanical study on the herbaceous vegetation on karst terrains in the region between villages of Dragoman and Beledie Chan. In parallel, some studies on the forest vegetation were performed. In order to clarify the development of the vegetation cover in the nearest historical past, a special attention was paid to the structure and composition of the forest cenoces and their interrelations with the herbaceous vegetation.

The vegetation in the territory of interest is characterized by a high floristic and phytosociological diversity. The main part of the area is covered by herbaceous communities (forest communities are not included in the present study). The plant cover of a large part of the territory was studied in detail by VELCHEV [1962]. According to the biological and ecological characteristics, florogenetic and coenotic relationships of the vegetation, he classified the vegetation into the following types: 1. Meadow type (with main species Poa sylvicola, Agrostis capillaris, Anthoxanthum odoratum, Festuca pratensis, Alopecurus 
pratensis); 2. Steppe type (main species are Festuca valesiaca, Festuca stojanovii, very close biologically and ecologically to the steppe species Festuca sulcata, together with Koeleria macrantha, Stipa capillata, Bromus inermis, Trifolium montanum, Lathyrus pannonicus, Astragalus pubiflorus, Hyacinthus leucophaeus, Adonis vernalis, Paeonia tenuifolia, Filipendula vulgaris, Salvia pratensis, S. nemorosa, S. nutans, Dictamus albus, Galium verum, Asperula glauca, Leucanthemum vulgare, Echium rubrum, Jurinea mollis and others); 3. Ephemero-ephemeroid type, consisting of Poa bulbosa, Haynaldia villosa and large number of species of the families Fabaceae, Liliaceae, Iridaceae; 4 Andropogon-type of vegetation (Chrysopogon gryllus, Dichanthium ischaemum); 5. Mountainous xerothermic fruticose vegetation: Satureja montana, Artemisia alba, Jurinea stoechadifolia, Thymus striatus and others; 6. Rocky vegetation: Achillea ageratifolia var. aizoon, Dianthus strictus var. kitaibelii, Alyssum sxatile, Satureja cristata etc. Concerning the floristic elements, the Mediterranean one predominates. VELCHEV [1962] classified to Mediterranean type the $3^{\text {rd }}$, $4^{\text {th }}$ and $5^{\text {th }}$ of the above-mentioned types. The steppe type keeps second position. This characteristic of the vegetation in the region of interest could be subjected to a modern analysis. However, it provides valuable information about the ecological and geographic character of the phytocoenoses in the region, which is a basis for distinguishing between the habitat types. This fact outlines the problem for adapting of Bulgarian vegetation, which possesses in many cases sub-Mediterranean and local specific features, to the habitat types of NATURA 2000, elaborated on the base of middle- and northern European vegetation.

A systematic and phyto-geographic analysis was performed on Chepan Mt. [ANGELOVA, TASHEV, 2004 a,b,c; TASHEV, ANGELOVA, 2005, 2006]. An assessment of the life forms of high plants and their vertical distribution in the mountain were done [ANGELOVA, TASHEV, 2005]. Phytocenoces with participation of Hyssopus officinalis ssp. aristatus in the region of Beledie Chan were described [RUSSAKOVA et al., 1999].

\section{Materials and methods}

In the period of June-August 2005 an investigation on the biodiversity of the habitats in relation to the project NATURA 2000 was carried out on part of the southern slope of Stara Planina Mt.(Western) and also the valley of Nishava river, Iskar gorge to the north of Eliceina. town, the northern part of Znepole region - Chepan Mt., the eminence of "Tri Ushi", Bezden-Ponor plateau, and the western part of Sofia region - Beledie Chan. The area of the studied territory is about $250 \mathrm{~km}^{2}$. The trace method was applied. The habitat types were described and their codes were pointed according to the guidelines for determination of habitats of European significance [KAVRAKOVA et al., 2005], the Interpretation manual for the habitats in European Union - Eur 15/2 (2002) and "Classification of the Paleo-arctic Habitats" (PAL. CLASS), version 1996.

The number written in front of the data for the investigated habitats is their consequent number from the terrain lists. The list of the species of conservation importance established for each habitat is presented after the asterisk mark $\left(^{*}\right)$. Plant specimets were deposide in the Herbarium of the Institute of Botany, Bulgarian Academy of Sciences (SOM).

\section{Results}

In the investigated regions 11 different habitat types of European significance of herbaceous and shrub communites were established.

40A0. PAL.CLASS.: 31.8B12 (Subcontinental peri-Pannonic scrubs).

The sub-continental peri-pannonic bush communities have limited distribution in the region of study. Several small parts were found. The main argument characterizing this habit is the presence of Amygdalus nana, together with some other species, characterizing this habitat type: Inula hirta, Teucrium chamaedrys, Adonis vernalis, Geranium sanguineum, Syringa vulgaris, Paeonia tenuifolia (endangered species in Bulgaria) and some others. 
Several other rare, endangered or endemic species occur within the communities of Amygdalus nana, thus increasing the value of the habitat type. These are Tulipa urumoffii-a rare species, Bulgarian endemic, Edraianthus sebicus - a rare species, Balkan endemic, and Sempervivum erytraeum - Balkan endemic.

25. FN 56; Stara Planina Mt.(Western); between the villages Ponor and Vasiliovci; 890 m a.s.1.; N: 42 ${ }^{\circ} 5^{\prime} 05.6^{\prime \prime}$; E: 2306'35.5"; 19.06.2005. *Paeonia tenuifolia, Adonis vernalis.

46. FN 65; Stara Planina Mt.(Western); Chepan Mt.; 1175 m a.s.1.; N: 4256'47.4"; E: 2257'49.0"; 24.08.2005. *Tulipa urumoffii, Edraianthus serbicus.

47. FN 65; Stara Planina Mt.(Western); Chepan Mt.; peak Petrovski Krust; $1206 \mathrm{~m}$ a.s.1.; N: 4256'50.8"; E: 2257'36.0"; 24.08.2005.*Tulipa urumoffii, Sempervivum erytraeum.

Plant species established: Adonis vernalis, Alopecurus pratensis, Amygdalus nana, Anthyllis vulneraria, Artemisia alba, Carpinus orientalis, Carex tomentosa, Centaurea scabiosa, Cachris alpina, Dianthus giganteus, Dictamnus albus, Edraianthus serbicus, Inula germanica, Hyssopus officinalis, Gladiolus imbricatus, Festuca valesiaca, Koeleria macrantha, Origanum vulgare, Poa angustifolia, Pastinaca hirsuta, Paeonia tenuifolia, Plantago argentea, Polygala vulgaris, Satureja montana, Salvia nutans, Sanguisorba officinalis, Sedum annuum, Sempervivum erythraeum, Stachys recta, Stipa pennata, Stachys officinalis, Syringa vulgaris, Teucrium chamaedrys, Thymus spp., Tragopogon pratensis, Tulipa urumoffii, Vicia tenuifolia, V. pannonica, Vinca sp., etc.

6110. PAL.CLASS.: 34.11 (Rupicolous calcareous or basophilic grasslands of AlissoSedion albi)

This habitat type occurs in many places in the region, but at each point of occurrence occupy quite small areas. The species composition is relatively uniform - most frequent species are Sedum album, S. acre, Alyssum minimum, Minuartia setacea, Poa badensis, Poa bulbosa, Paronichia cephalotes, Teucrium montanum. VelCHEV [1962] classified a significant part of this vegetation to the rocky vegetation group.

43. FN 67; Stara Planina Mt.(Western); to the north-west of Gubesh village; $1370 \mathrm{~m}$ a.s.1.; N: 4305'24.8"; E: 2304'01.7"; 24.06.2005.

Plant species established: Acinos arvensis, Alyssum alyssoides, Medicago minima, Poa badensis, Paronychia cephalotes, Minuartia setacea, Potentilla cinerea, Sanguisorba minor, Sedum album, S. acre, S. alpestre, Scleranthus annuus, Sempervivum spp., Teucrium montanum, etc.

6210. PAL.CLASS.: 34.316 (Semi-natural dry grasslands and shrubland facies on calcareous substrates - Festuco-Brometea) (important habitats of orchids).

This unit contains phytocoenoses formed on relatively well-developed and rich soils under xerophyte and meso-xerophyte conditions, and where orchids (Orchidaceae) could be found in most parts. Most species are not rare at national scale, but are rare at regional scale, and some of them are reported for a first time. The most frequent are Hyacintella leucophaea, Orchis coriphora, Ophrys apifera. Anacamptis pyramidalis and Orchis purpurea are represented by a few individuals in the communities studied. Main ediphicators are Festuca valesiaca (referred to as Festuca pseudovina by Velchev, 1962), Festuca stojanovi, Chrysopogon gryllus, Dichanthium ischaemum, Stipa capillata, Stipa pennata agg., Koeleria macrantha, but the composition of the communities is enriched by steppe species: Paeonia tenuifolia, Carex humilis, Poa bulbosa, Filipendula vulgaris, Teucrium chamaedrys, Bromus riparius, B. mollis, Medicago falcata, Carex caryophyllea, Convolvulus canthabrica and others. The terrains occupied are dry, with variable watter supply and the main ediphicators are xerothermic cereal species.

23. FN-56; Stara Planina Mt.(Western); to the north-west of Cheparlintsi village; 690 $\mathrm{m}$ a.s.l.; N: $43^{\circ} 02^{\prime} 19.8^{\prime \prime}$; E: $22^{\circ} 54^{\prime} 31.8^{\prime \prime} ; 18.06 .2005$. On area of roughly $250 \mathrm{~m}^{2} 5$ individuals 
of * Ophrys apifera (SOM - 162516), 4 individuals of *Anacamptis pyramidalis (SOM 162375) and 2 individuals of *Orchis purpurea were determined.

25. FN 56; Stara Planina Mt.(Western); between Ponor and Vasiliovci villages; $890 \mathrm{~m}$ a.s.1.; 19.06.2005.

36. FN-67; Stara Planina Mt.(Western); to the south-east of Smolcha village; $990 \mathrm{~m}$

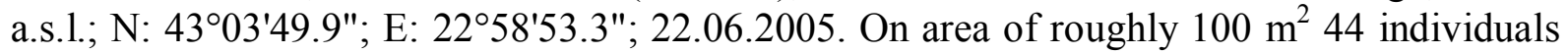
of * Ophrys apifera (SOM - 162517) and furthermore 50 individuals of *Orchis coriophora were determined.

37. FN-67; Stara Planina Mt.(Western); to the south-east of Smolcha village $990 \mathrm{~m}$ a.s.1.; N: $43^{\circ} 03^{\prime} 54.0^{\prime \prime}$; E: $22^{\circ} 58^{\prime} 55.5^{\prime \prime} ; 22.06 .2005$. On area of roughly $500 \mathrm{~m}^{2} 9$ individuals of *Ophrys apifera (SOM - 162518), 76 individuals of*Orchis coriophora and 11 individuals of *Himantoglossum caprinum (SOM - 162521) were determined.

38. FN-67; Stara Planina mt.(western); near village of Burlia; $960 \mathrm{~m}$ a.s.l.; N: $43^{\circ} 06^{\prime} 09.3^{\prime \prime}$; E: 22 $2^{\circ} 9^{\prime} 10.1^{\prime \prime} ; 22.06 .2005$. On area of roughly $150 \mathrm{~m}^{2} 10$ individuals of *Ophrys apifera and forthermore 9 individuals of *Orchis coriophora were determined.

39. FN-67; Stara Planina Mt.(Western); to the south of Komshtiza village; $1130 \mathrm{~m}$ a.s.1.; N: $43^{\circ} 06^{\prime} 04.1^{\prime \prime}$; E: $23^{\circ} 00^{\prime} 31.4^{\prime \prime} ; 22.06 .2005$. On area of roughly $50 \mathrm{~m}^{2} 19$ individuals of *Ophrys apifera (SOM - 162515) were determined.

45. FN-66; Stara Planina Mt.(Western); to the north-west of Ravna village; $1185 \mathrm{~m}$ a.s.1.; N: 4303'05.7"; E: 2300'27.3"; 24.06.2005.

50. FN-97; Stara Planina Mt.(Western); between the villages Lakatnik and Opletnia; 430 m a.s.1.; N: $43^{\circ} 03^{\prime} 55.2^{\prime \prime}$; E: $23^{\circ} 22^{\prime} 00.5^{\prime \prime} ; 8.07 .2005$.

54. GN-17; Stara Planina Mt.(Western); between the villages Ignatica and Rashkovo, along the road; $510 \mathrm{~m}$ a.s.1.; N: 4302'52.3"; E: 23³6'59.3"; 10.07.2005.* Orchis laxiflora, O. coriophora.

Plant species established: Adonis vernalis, A. flammea, Anacamptis pyramidalis, Anthyllis vulneraria, A. montana, Achillea clypeolata, Agrimonia eupatoria, Ajuga laxmannii, A. chamaepitys, Artemisia alba, Astragalus glycyphyllus, A. wilmottianus, Brachypodium pinnatum, Briza media, Bromus erectus, B. inermis, Carex cariophyllea, C. halleriana, Carlina vulgaris, C. acantifolia, Centaurea scabiosa, Convolvulus canthabrica, Chrysopogon gryllus, Crataegus monogyna, Dichantium ischaemum, Digitalis lanata, Eryngium campestre, Euphorbia nicaensis, Festuca valesiaca, Filipendula vulgaris, Fraxinus ornus, Fragaria vesca, Globularia apphyllanthes, Helleborus odorus, Himantoglossum caprinum, Hyacintella leucophaea, Hypericum perforatum, H. rumeliacum, Koeleria macrantha, Leontodon crispus, Linum tenuifolium, Melica ciliata, Nonnea pulla, Ophrys apifera, Orchis laxiflora, O. purpurea, O. coriophora, Origanum vulgare, Orlaya grandiflora, Plantago media, Polygala vulgaris, Paeonia tenuifolia, Poa angustifolia, P. badensis, Potentilla argentea, P. cinerea, Phleum phleoides, Salvia nemorosa, Sanguisorba minor, Satureja montana, Salix elaeagnos, Sideritis montana, Stachys recta, Stipa pennata, Syringa vulgaris, Teucrium polium, T. chamaedrys, Thymus sp., Trifolium montanum, Veronica austriaca, Vicia cracca, etc.

6230. PAL.CLASS.: 36.318 (Species rich Nardus grasslands, on siliceous substrates in mountain areas).

34. FN 77; Stara Planina Mt.(Western); to the north of Ginci village; $1240 \mathrm{~m}$ a.s.1.; N: 4306'29.2"; E: 2305'56.7"; 21.06.2005. Juniperus spp.(30\%), Nardus stricta (70\%)

Plant species established: Agrostis capillaris, Alchemilla glaucescens, Campanula patula ssp. epigaea, Centaurea triumfetti, Festuca nigrescens, F. pratensis, Hieracium hoppeanum, Hypericum perforatum, H. maculatum, Juniperus communis, Juniperus pygmaea, Leontodon automnalis, Nardus stricta, Poa pratensis, P. sylvicola, Polygala vulgaris, Taraxacum officinale, Thymus vandasii, Trifolium pretense, T .repens, T. patens, Verbascum pannosum, Veronica chamaedrys, Viola tricolor, etc. 
6240. PAL.CLASS.: 34.315 (Sub-Pannonic steppic grasslands).

The classification affiliation of this habitat type named Sub-Pannonian steppe herbaceous communities is discussional. The main arguments are that the unit 34.315 of Pal. Class. Does not occur in Bulgaria, and the vegetational type is classified to 34.316, which is labeled by code 6210 in NATURA 2000. Usually in 6240 we include steppe herbaceous communities composed of tuft grasses, chamaephytes and perennial plants of the alliance Festucion valesiacae, situated on southern slopes, on soils having AC horizons. The terrains are eroded in most cases; the soil is shallow rendzik Leptosols, often with rocks at the surface. In rare cases the soils are degraded eutric Planosols. The water supply is highly variable and during the summer the air and soil temperatures are high. This unfavourable abiotic environment results in open plant communities and in many places the plant cover is about 60 $\%$. The phytocoenoses are xerothermic ones. Highly represented are the following taxa: Satureja montana subsp. kitaibelii (a Balklan endemic), Artemisia alba, Jurinea stoechadifolia, Helianthemum canum, Dichanthium ischaemum, Hippocrepis comosa, Sideritis montana, Thymus striatus, Thymus pannonicus, Thymus longicaulis, Carex humilis, Poa badensis and some others. The plant communities are characterized by very rich floristic composition. Rarely occurring species include Paeonia tenuifolia, Teucrium chamaedrys, Medicago minima, Asperula cynanchica, Cerastium brachypetalum, Filipendula vulgaris, Arenaria serpillifolia, Satureja suaveolens, Hyssopus officinalis etc. Some communities are dominated by the Bulgarian endemic subspecies Festuca stojanovii. There are some rare species, like the Bulgarian endemic Tulipa urumoffii and some others.

1. FN 75; Stara Planina Mt.(Western); the southern slope, above Bezden village; 650 m a.s.1.; N: 4253'20.1"; E: 23066'39.6"; 14.06.2006.

2. FN 75; Stara Planina Mt.(Western); the southern slope, above Bezden village; 780 m a.s.1.; 14.06.2005.

3. FN 75; Stara Planina Mt.(Western); the southern slope, above Bezden village; 780 m a.s.1.; 14.06.2005.

7. FN 85; Stara Planina Mt.(Western); the south-eastern slope, above Gradec village; 820 m a.s.1.; N: 4253'02.3"; E: 23ํ'12'41.5"; 15.06.2005.

17. FN 75; Stara Planina Mt.(Western); the western slope, above the road to town Godech, in the region of Buchin Prohod; $850 \mathrm{~m}$ a.s.1.; N: 42 $57^{\prime} 30.8^{\prime \prime}$; E: $23^{\circ} 09^{\prime} 29.8^{\prime \prime}$; 16.06.2005.

24. FN 55; Stara Planina Mt.(Western); to the southern slope of Chepan Mt.; $820 \mathrm{~m}$ a.s.1.; N: 4256'41.3"; E: 2259'32.7"; 19.06.2005.

26. FN 65; Stara Planina Mt.(Western); the southern slope of the eminence "Tri Ushi", above Aldomirovsko marsh; 700 m a.s.1.; N: 4253'58.8"; E: 2300'12.7"; 20.06.2005.

27. FN 65; Stara Planina Mt.(Western); the southern slope of the eminence "Tri Ushi", above Aldomirovsko marsh; $870 \mathrm{~m}$ a.s.1.; N: 4254'13.2"; E: 2300'11.5"; 20.06.2005.

28. FN 65; Stara Planina Mt.(Western); the southern slope of the eminence "Tri Ushi", above Aldomirovsko marsh; $780 \mathrm{~m}$ a.s.1.; N: 4254'14.4"; E: 2259'07.6"; 20.06.2005.

29. FN 65; Stara Planina Mt.(Western); the southern slope on the eminence "Tri Ushi”, above Aldomirovsko marsh; 755 m a.s.1.; N: 4254'09.9"; E: 2259'04.4"; 20.06.2005.

Plant species established: Acinos alpinus, Achillea clypeolata, Aegilops cylindrica, Agropyron pectiniforme, Allium sp., Alyssum alyssoides, Artemisia alba, Astragalus onobrychis, Asperula cynanchica, Bromus erectus, Cerasus mahaleb, Convolvulus cantabrica, Chrysopogon gryllus, Crataegus monogyna, Carex humilis, Eryngium campestre, Festuca valesiaca, Koeleria macrantha, Lathyrus nissolia, Linum tenuifolium, Lotus corniculatus, Medicago falcata, M. minima, Melica ciliata, Orlaya grandiflora, Poa badensis, Rhodax canus, Rosa sp., Sanguisorba minor, Satureja montana, Sedum album, S. acre, Sideritis montana, Stipa pennata, S. pulcherrima, Teucrium chamaedrys, T. polium, Trifolium spadiceum, Xeranthemum annuum, etc. 
62A0. PAL.CLASS.: 34.75 (Eastern sub-mediteranian dry grasslands (Scorsoneratalia villosae).

This habitat type develops on dry and shallow skeletal soils with a substantial participation of Mediterranean species. In most cases it occurs on southern slopes and the composing species are of xerothermic or southern origin: Carex humilis, Bromus moesiacus, Chrysopogon gryllus, Dichanthim ischaemum, Festuca valesiaca, Artemisia alba, Hyssopus officinalis, Fumana procumbens, Teucrium polium, Scorzonera hispanica, Potentilla cinerea and others. The composition is enriched also by rare and endemic species: Edraianthus serbicus, Tragopogon balcanicum, Sempervivum erythraeum, Astragalus wilmottianus.

19. FN 75; Stara Planina Mt.(Western); the spot Beledie Chan; $820 \mathrm{~m}$ a.s.l.; N: 42॰53'51.7"; E: 2310'05.6"; 18.06.2005.

48. FN 65; Stara Planina Mt.(Western); Chepan Mt.; 1145 m a.s.1.; N: 4256'52.4"; E: 2256'53.8"; 24.08.2005. *Edraianthus serbicus, Astragalus wilmottianus, Adonis vernalis.

49. FN 55; Stara Planina Mt.(Western); Chepan Mt.; above Dragoman town; $905 \mathrm{~m}$ a.s.1.; N: 4256'40.6"; E: 2255'55.8"; 24.08.2005. *Astragalus wilmottianus, Tragopogon balcanicum, Sempervivum erythraeum.

Plant species established: Adonis vernalis, Agropyron pectiniforme, Astragalus wilmottianus, Carex humilis, Coronilla varia, Chrysopogon gryllus, Crataegus monogyna, Dichantium ischaemum, Edraianthus serbicus, Eryngium campestre, Festuca valesiaca, Fumana procumbens, Hypericum rumeliacum, Koeleria splendens, Medicago minima, Potentilla cinerea, Rosa sp., Sanguisorba minor, Satureja montana, Sideritis montana, Sempervivum erythraeum, Stipa sp., Teucrium polium, Tragopogon balcnicum, etc.

The distinguishing of three of the main habitats in the region - 6210, 6240 and $62 \mathrm{~A} 0-$ is rather difficult and somewhat under discussion. The territory studied is situated in the transitional-continental part of Bulgaria, where different plant communities are formed by geoelements from continental, steppe and Mediterranean Europe. Many of them are widely distributed, have similar ecological characteristics and participate together in the formation of the plant communities. There are also controversies in the literature concerning the affiliation of many species to one or another category. This concerns, for example, Chrysopogon gryllus, Dichanthium ischaemum, Festuca valesiaca, Satureja montana and some others. At the same time, some rare and endemic taxa take part in the composition of communities, sometimes playing leading role, which results in specific features of the plant communities, characterisng the habitat types. The book of RoDWELL et al. [2002] does not include syntaxa of the alliance Festuco-Brometea, related to EUNIS classification of habitats of Southeastern Europe. The Bulgarian experts also do not have a unified opinion for solving these problems. In the present paper we discuss results of a study on relatively small area, which provides a basis for some contribution to the solving of these problems.

6410. PAL.CLASS.: 37.31 (Molinia medous on calcareous, peaty or clavey silt-laden soils (Molinion caeruleae).

15. FN 76; Stara Planina Mt.(Western); to the east of Shuma village; $725 \mathrm{~m}$ a.s.l.; N: 42॰59'21.5"; E: 2305'49.2"; 16.06.2005.

52. GN 06; Stara Planina Mt.(Western); above Osenovlak village; $1145 \mathrm{~m}$ a.s.l.; N: 4257'36.4"; E: 2334'33.6"; 8.07.2005.

Plant species established: Carex disticha, C. distans, Deschampsia caespitosa, Equisetum palustre, Eleocharis palustris, Epilobium palustre, Molinia caerulea, Sanguisorba officinalis, etc.

6440. PAL.CLASS.: 37.23 (Alluvial meadows of river valleys of Cnidion dubii). 
33. FN 77; Stara Planina Mt.(Western); to the south-east of Brakiovci village; $970 \mathrm{~m}$

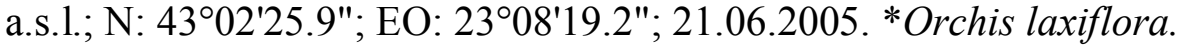

Plant species established: Agrostis stolonifera, Alopecurus pratensis, Festuca pratensis, Orchis laxiflora, Poa palustris, Ranunculus acris, Symphytum officinale, etc.

6510. PAL.CLASS.: 38.2 (Lowland hay meadows /Alopecurus pratensis, Sanguisorba officinalis/).

The group of meadow habitats has a limited distribution in the region of study. It consists of mesophyte communities of alliance Molinio-Arrhenatheretea. They are represented by several spots, where the main ediphicators are the mesophyte cereal species Poa sylvicola, Festuca pratensis, Alopecurus pratensis, Cynosurus cristatus, Deschampsia caespitosa, with the presense of Knautia arvensis, Leucanthemum vulgare, Trifolium pratense, Stellaria graminea, Ranunculus acris.

8. FN 85; Stara Planina Mt.(Western); the meadows below Tzarichina village; $820 \mathrm{~m}$ a.s.1.; N: 4253'13.2"; E: 23ำ13'48.9"; 15.06.2006.

9. FN 85; Stara Planina Mt.(Western); to the south-east of Chibaovci village; $860 \mathrm{~m}$ a.s.1.; N: 4255'41.8"; E: $23^{\circ} 15^{\prime} 23.9^{\prime \prime} ; 15.06 .2006$.

10. FN 85; Stara Planina Mt.(Western); the region between the Chibaovci and Drumsha villages; $870 \mathrm{~m}$ a.s.1.; N: 4256'02.9"; E: 2313'57.1"; 15.06.2006.

11. FN 75; Stara Planina Mt.(western); the spot Beledie Han, meadows on the road fork to village Ponor ; $870 \mathrm{~m}$ a.s.1.; N: 4254'52.1"; E: 2309'47.1"; 15.06.2006.

12. FN 76; Stara Planina mt.(Western); in the west of the road to Sofia - Godech; before village Shuma; 800 m a.s.1.; N: 4256'30.1"; E: 2309'35.2"; 16.06.2006.

13. FN 76; Stara Planina Mt.(Western); on the road fork Sofia - Godech, before Shuma village; 770 m a.s.1.; N: 4258'54.6"; E: 2307'41.9"; 16.06.2006. *Orchis laxiflora.

14. FN 76; Stara Planina Mt.(Western); to the south of Shuma village; $730 \mathrm{~m}$ a.s.1.; N: 42॰59'26.8"; E: 2305'07.8"; 16.06.2006.

16. FN 76; Stara Planina Mt.(Western); in the region near town of Godech, by the fountain on the road fork to Shuma village; $760 \mathrm{~m}$ a.s.1.; N: $42^{\circ} 59^{\prime} 02.0^{\prime \prime}$; E: $23^{\circ} 07^{\prime} 26.7^{\prime \prime}$; 16.06.2006.

18. FN 75; Stara Planina Mt.(Western); to the west of Ponor village; $960 \mathrm{~m}$ a.s.l.; N: 4255'56.5"; E: 2306'39.0"; 16.06.2006. * Stachys officinalis, Gladiolus sp., Gymnadenia conopsea, Orchis laxiflora, O. morio.

20. FN-56; Stara Planina Mt.(Western); above the mine of Stanianci ; $660 \mathrm{~m}$ a.s.1.; N: 4302'44.5"; E: 2254'47.7"; 18.06.2006. *Ophrys apifera f. flavescens Rosb. (SOM 162514) and $*$ Orchis coriophora.

21. FN 66; Stara Planina Mt.(Western); to the north of Chepurlinci village; $665 \mathrm{~m}$

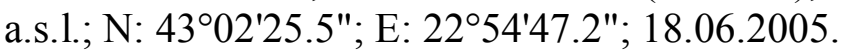

22. FN 56; Stara Planina Mt.(western); to the west of Golesh village; $720 \mathrm{~m}$ a.s.l.; N: $43^{\circ} 02^{\prime} 45.3^{\prime \prime}$; E: $22^{\circ} 57^{\prime} 08.8^{\prime \prime} ; 18.06 .2005$.

30. FN 66; Stara Planina Mt.(Western); to the west of Kalenovci village; $615 \mathrm{~m}$ a.s.l.; N: 42॰59'06.5"; E: 2256'50.6"; 20.06.2006.

31. FN 66; Stara Planina Mt.(Western); between Kalenovci and Bukorovci villages; 615 m a.s.1.; N: 4259'18.4"; E: 2257'45.8"; 20.06.2006.

32. FN 86; Stara Planina Mt.(Western); above Breze village; $800 \mathrm{~m}$ a.s.1.; N:

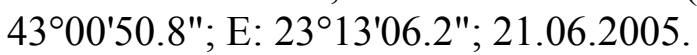

40. FN 67; Stara Planina Mt.(Western); to the south of Gubesh village; $1065 \mathrm{~m}$ a.s.1.; N: 4304'55.1"; E: 2302'18.3"; 24.06.2006. 
41. FN 67; Stara Planina Mt.(Western); to the south-east of Gubesh village; $1185 \mathrm{~m}$ a.s.1.; N: 4304'50.0"; E: 2303'58.7"; 24.06.2006. *Dactylorhiza incarnata (SOM - 162520), Orchis purpurea (SOM - 162524), O. coriophora (SOM - 162523).

51. GN 05; Stara Planina Mt.(Western); place Gabrovnica, by the course of river Gabrovnica; 1150 m a.s.1.; N: 4303'49.9"; E: 2258'53.3"; 8.07.2005. Salix elaeagnos (SOM - 162414) (new location for Bulgaria).

53. GN 17; Stara Planina mt.(western); near Ignatica village; $540 \mathrm{~m}$ a.s.l.; $\mathrm{N}$ : 4303'33.7"; E: 2336'27.1"; 10.07.2005. Salix elaeagnos (SOM - 162413) (new location for Bulgaria).

Plant species established: Alopecurus pratensis, Asphodelus albus, Astragalus glycyphyllos, Briza media, Centaurea jacea, Cirsium canum, Chamaespartium sagittale, Cynosurus cristatus, Dactylorhiza incarnata, Eryngium campestre, Festuca arundinacea, F. pratensis, Filipendula vulgaris, Geranium sanguineum, Gladiolus communis, Gymnadenia conopsea, Inula germanica, Holcus lanatus, H. mollis, Knautia arvensis, Leucanthemum vulgare, Moenchia mantica, Ophrys apifera, Orchis coriophora, O. laxiflora, O. morio, O. purpurea, Pastinaca hirsuta, Potentilla alba, Rhinanthus rumelica, Sanguisorba officinalis, Stachys officinalis, Stellaria graminea, Trifolium resupinatum, T. pratense, T. patens, Veronica austriaca, Verbascum phoeniceum etc.

6520. PAL.CLASS.: 38.31 (Mountain hay meadows).

Several occurrences of this habitat type were found on the slopes of Stara planina. The habitat type is characterised by diverse floristic composition, the more reresentative species being Agrostis capillaris, Anthoxanthum odoratum, Briza media, Poa pratensis, Phleum pratensis, Chamaespartium sagittale, Cerastium arvense, Filipendula vulgaris, Gymnadenia conopsea, Orchis coriophora.

35. FN 76; Stara Planina Mt.(Western); to the north of Ginci village; $1142 \mathrm{~m}$ a.s.1.; N:

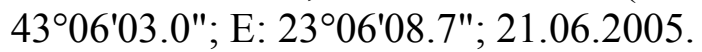

42. FN 67; Stara Planina Mt.(Western); to the north-east of Gubesh village; $1345 \mathrm{~m}$

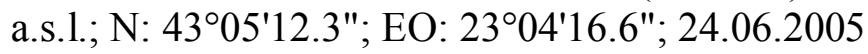

43. FN 67; Stara Planina Mt.(Western); to the north-west of Gubesh village; $1370 \mathrm{~m}$ a.s.1.; N: 4305'24.8"; E: 2304'01.7"; 24.06.2005.

52. GN 05; Stara Planina Mt.(Western); above Osenovlak village; $1130 \mathrm{~m}$ a.s.l.; N: 4257'36.4"; E: 2334'29.9"; 8.07.2005.* Silene roemeri, Gymnadenia conopsea (SOM 162374), Orchis coriophora.

55. GN 16; Stara Planina Mt.(Western); above Rashkovo village; $700 \mathrm{~m}$ a.s.1.; N: 4301'23.1"; E: 2337'37.5"; 9.07.2005.

Plant species established: Agrostis capillaris, Anthoxanthum odoratum, Briza media, Chamaespartium sagittale, Cerastium arvense, Chaerophyllum hirsutum, Gymnadenia conopsea, Filipendula vulgaris, Medicago minima, Orchis coriophora, Poa badensis, P. pratensis, P. sylvicola, Potentilla cinerea, Phleum pratense, Plantago media, Primula elatior, Teucrium chamaedrys, Sanguisorba officinalis, Sedum spp., Silene roemeri, Valeriana officinalis, Viola tricolor, etc.

8210. PAL.CLASS.: 62.1. Calcareous rocky slopes with chasmophytic vegetation.

This habitat is distributed scarcely in the region of study but some of the species occurring here are very important from conservation point of view, because some of them are rare or endemic species. These include Achillea serbica - a Balkan endemic, forming relatively small spots, Dianthus noeanus, Silene flavescens, Asplenium trichomanes, A. rutamuraria, Cerasus mahaleb, Cotinus coggygria, Syringa vulgaris etc.

56. FN 56; Stara Planina Mt.(Western), above the road between Berende, Izvor and Kalotina villages; 540 m a.s.1.; N: 4259'50.4"; E: 2252'41.0"; 19.06.2005. 
Plant species established: Asplenium trichomanes, A. ruta-muraria, Carpinus orientalis, Cerasus mahaleb, Cotinus coggygria, Syringa vulgaris, etc.

\section{Discussion and conclusion}

The investigated region is characterized with a highly intersected terrain, which creates prerequisites for the formation of different types of habitats. On about $250 \mathrm{~km}^{2} 11$ different habitat types of herbaceous and shrub phytocenoces were established.

In the valleys of several rivers in more or less leveled terrains, mesophilic meadow phytocenoces have been formed. In places such phytocenoces exist on the slopes of more closed river valleys.

The habitats occupying very rocky slopes, which are with dominant southern or with southern component exposure and have poorly developed soil cover are area-prevailing. Additionally, the calcareous main rock expresses the xerotermic character of this group of habitats.

The floristic composition in the separate parcels is very rich although often the communities are opened and possess low coverage density. Large part of the species is well adapted to the conditions in the neighbouring groups of habitats and has wide distribution. The anthropogenic activity also contributes to the extension of the distribution range of some species.

Furthermore, the investigated territory is a cross area of several floristic regions. Consequently, investigations aiming elaboration of floristic classification for the region are required in order to distinguish and prove the different types of habitats with similar characteristic features of the abiotic factors and composition of the phytocenoces as: $6210-$ Semi-natural dry grasslands and shrubland facies on calcareous substrates of FestucoBrometea class (where location of the species Ophrys apifera, rare for Bulgaria, were established), 6240 - Sub-Pannonic steppic grasslands and 62A0 - Eastern sub-Mediterranean dry grasslands. Similar conclusion is also reasonable for separation of the meadow habitats to low-land (Code 6510) and mountainous (code 6520), as the main part of the mesophilic hay harvesting meadow cenoces has altitudinal distribution range including the two types habitats. They contain some rare species as Silene roemeri, Gymnadenia conopsea, Orchis coriphora.

The physical-geographic features of the environment in the investigated region give opportunities for the development of open calcareous grasslands of Alisso-Sedio (code 6110), which occupy spots of several square meters in many places in the boundaries of the abovementioned groups of habitats.

A habitat, rarely found on calcareous silt-laden soils in the investigated region, is 6410 Molinia meadows. The same can be said for 6230 - Species rich Nardus grasslands, which can be explained in this case with the limited boundaries of the investigated area - mainly outside of the distribution range of this habitat types.

The habitats included in the group 40A0 - Subcontinental peri-Pannonic scrub associations in Chepan Mt. and Bezden-Ponor Plateau are of special interest. Their composition includes rare species as Paeonia tenuifolia, Tulipa urumoffii, Edraianthus serbicus, Cachris alpina, Tulipa urumoffii, Sempervivum erythraeum, some of which have strongly expressed spoted distribution range on the territory of Bulgaria.

The investigated area is also rich in species of Orchidaceae, which are rare for Bulgaria. This fact imposes special measures for conservation of these species to be introduced, via defining their localities as protected areas.

\section{References}

ACT for changes and amendments of the Biodiversity Act of Bulgaria. - 2005. - State Gazete. -88 p.

Angelova K., Tashev A. Complex analysis of the life forms of flowering plants in Mount Chepan and their vertical ranges of spread in altitude // Trakija Journal of Science. - 2005. - (in press)

Angelova K., TASHeV A. Investigation on Cachrys alpina Bieb. localities in Chepan Mt. (Western Balkan Range) //Scientific works of Plovdiv University - 2004a. - Vol. XLIX. - P.111-116. 
Angelova K., TASHeV A. Investigation on Tragopogon balcanicum Vel. localities in Chepan Mt. (Western Balkan Range) // Scientific works of Plovdiv University. - 2004b. - Vol. XLIX. - P.117-122.

Angelova K., TAsheV A. Medical plants in Chepan Mt. //V National Scientific Conference with International Participation "Ecology and Health" (2004). - Plovdiv University Publ. House. - 2004c. - P. 471-476.

Assyov B., Dimitrov D., Vasilev R., Petrova A. Conspectus of the Vascular Flora of Bulgaria // Chorology and floral elements., BSBCP. - 2002. -422 p.

BIODIVERSITY Act of Bulgaria. - State Gazete, 2002. - 77 p.

EUROPEAN Nature Information System (EUNIS database v 2) http://eunis.eea.eu.int/habitats

INTERPRETATION manual of European Union Habitats. Eur 15/2. // FNCS "Green Balkans". - Plovdiv, 2002. $126 \mathrm{p}$.

Kavrakova V.D., Dimova M., Dimitrov R., Tzonev, Belev T. (eds.). Handbook for identification of habitats of European importance. - Sofia, 2005. - 128 p.

Rodwell J. S., Schaminee J. H. J., Mucina L., Pignatti S., Dring J., Moss. D. The Diversity of European vegetation. - Wageningen, April 2002. - 168 p.

Russakova V.E,.GenOVA, PeTrova S. Ecological and phytocociological characteristic of Hyssopus officinalis ssp. aristatus (Godr.) Briq. In Bulgaria // Rast. resursi. - 1999. - Vol. 35, N 2. - P. 131-135.

Tashev A., Angelova K. Floristic Investigations in Mount Chepan (Western Balkan Range) // Silva Balcanica. - 2006. - Vol. 7, N 1. (in press)

VelcheV V. The herbaceous cover of calcareous terrains in the region Dragoman-Beledie-Chan, district of Sofia. - Publishing house of the Bulgarian Academy of Sciences, Sofia, 1962. - 132 p.

Рекомендує до друку

Отримано 25.11.2009 p.

I.I. Мойсієнко

Author's address:

A. Tashev

Department of Dendrology, Faculty of Forestry

University of Forestry

10 Kl.Ohridski Blvd.

Sofia, 1756,

Bulgaria

A. Vitkova, V. Russakova

Institute of Botany

23 Acad. G.Bonchev St.

Sofia, 1113

Bulgaria
Author's address:

A. Tashev

Department of Dendrology, Faculty of Forestry

University of Forestry

$10 \mathrm{Kl}$.Ohridski Blvd.,

Sofia, 1756,

Bulgaria

A. Vitkova, V. Russakova

Institute of Botany

23 Acad. G.Bonchev St.

Sofia, 1113

Bulgaria 